\title{
Incorporating Intermediate-Severity Disturbances in Oak Stand Development
}

\author{
Justin L. Hart ${ }^{1, *}$ and Lauren E. Cox ${ }^{2}$ \\ 1 Department of Geography, University of Alabama, Tuscaloosa, AL 35487, USA \\ 2 Department of Environmental Science, Policy, and Management, University of California, \\ Berkeley, CA 94720, USA; lecox@berkeley.edu \\ * Correspondence: hart013@ua.edu; Tel.: +1-205-348-1673; Fax: +1-205-348-2278
}

Received: 25 July 2017; Accepted: 3 August 2017; Published: 5 August 2017

\begin{abstract}
We propose a conceptual framework for the development of closed canopy oak (Quercus) stands that incorporates the influence of intermediate-severity canopy disturbance events, provides for the possibility of multiple developmental pathways, and does not narrowly define an endpoint given the stochastic nature of natural disturbances. The proposed model differs from the current oak stand development model in three primary ways. First, our proposed model acknowledges more than one mixed stage of development after an intermediate-severity disturbance based on the pre-disturbance condition and disturbance agent. Second, we suggest that these discrete mixed stages may progress in their development along different pathways and stands may be structurally dissimilar when they reach the complex stage. Third, we contend that the complex stage of development in oak stands is not usually achieved in the absence of the mixed stage because the return interval of these events is shorter than the period required for oak stands to reach the complex developmental stage via gap-phase processes alone. Our proposed framework for oak stand development should aid decision making in oak-dominated systems.
\end{abstract}

Keywords: disturbance; oak (Quercus); stand development; structure

\section{Introduction}

The ability to forecast stand growth and development is critical in forest management as some degree of predictability is required for decision making [1]. Thus, stand development models provide a basis for long-term forest planning. Oliver and Larson [2] provided a process-based model of growth and development for even-aged stands following catastrophic disturbance. In this model, stand development is divided into four discrete phases based primarily on competition for growing space. Listed sequentially, these are stand initiation, stem exclusion, understory reinitiation, and complex stages of development. Each phase exhibits unique stand structures and marks a discrete period in the development of the stand. The Oliver and Larson [2] model established the relationships between canopy disturbance events and the progression of stands along the developmental pathway from one stage to the next. Based on the Oliver and Larson [2] model of stand development, Johnson et al. [3,4] established a conceptual model for the development of oak (Quercus) stands (Figure 1). Johnson et al. [4] categorized canopy disturbances based on spatial extent, severity, and frequency, and disturbance events were broadly grouped as stand initiating (i.e., catastrophic), incomplete stand-scale (i.e., intermediate-severity events too localized to be classed as stand initiating and too large to be classed as gap scale), or gap scale (i.e., localized). Unlike the Oliver and Larson [2] model, the oak development model includes a mixed stage of development following intermediate-severity disturbances. Johnson et al. [4] noted that oak stands in the mixed developmental stage are ubiquitous because the events that create them are so common. Our purpose is to elaborate upon the importance of intermediate-severity disturbances 
and the resultant mixed stage of oak stand development, which are poorly understood and we contend underappreciated.

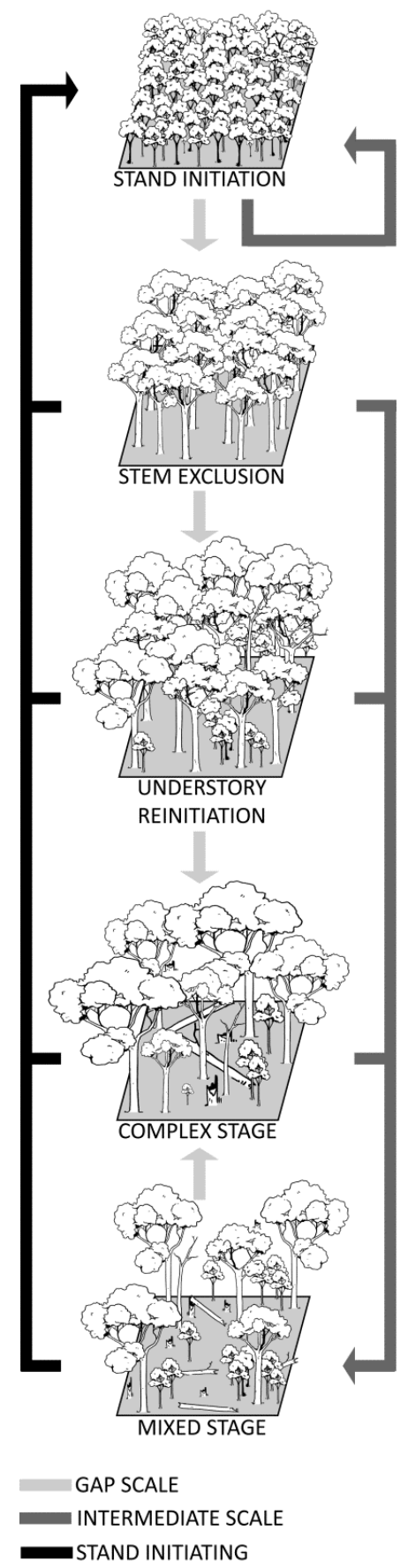

Figure 1. Model of oak stand development adapted from Johnson et al. [4] illustrating forest disturbances and their relation to stages of stand development and disturbance-recovery rates.

\section{Background on Disturbance and Development in Oak Stands}

In the oak stand development model, a catastrophic disturbance regenerates a new stand and so begins the stand initiation stage of development. In this developmental phase, stem density is high and thus, competition-induced mortality is common [5]. The trees that are able to overtop competitors (i.e., the winners) will eventually stratify to form a true canopy and crown closure marks the beginning of the stem exclusion stage of development. During the stem exclusion phase, competition-induced 
mortality remains high. The death of canopy trees during this stage results in relatively small gaps and freed growing space is rapidly captured by adjacent trees. By age 40 years the loss of these canopy trees is sufficient to result in increased rates of crown extension, height, and radial growth [6,7]. The recruitment of seedlings to sapling and small tree size classes marks the onset of the understory reinitiation stage of development. In oak stands, these understory stems are typically comprised of more shade-tolerant species [8-10]. With stand age, the size of canopy gaps created by a fallen tree increases and the ability of neighboring trees to close gaps decreases [5], but during the understory reinitiation phase, the gaps are still of the size that they most often close by lateral branch extension rather than subcanopy height growth [11-14]. The period in stand development when most gaps are sufficiently large so that they fill by subcanopy recruitment rather than lateral crown expansion marks the beginning of the complex developmental stage. At this stage, oak stands should exhibit structural characteristics that are typically used to define old-growth conditions. Some authors have proposed multiple old-growth stages for some forest cover types [15], but the current oak model recognizes a single complex stage.

In the current oak development model, the large gaps that characterize structure of the complex stage result from the gap-scale disturbance processes that occur continuously throughout prior stages of development. Although gaps in older stands occur less frequently than in earlier stages of development, because older stands contain fewer individuals and have reduced competition and mortality rates [5], the gaps in complex stage stands are relatively large. These gaps take long periods to close, which increases the probability of a new individual recruiting to the canopy [12,16-18]. In the current oak stand development model, the structural changes with maturity are driven by these gap-scale disturbance events in the absence of larger exogenous disturbances. Johnson et al. [4] posit that stand initiation commences following a catastrophic disturbance and development progresses from one stage to the next via gap-scale disturbances, but a disturbance of the intermediate scale alters development to the mixed stage. The model does not discern different mixed stages based on the stage of development at the time of the intermediate-severity disturbance or specific intermediate-severity disturbance agents. Once the mixed stage is created by an intermediate-severity disturbance, the stands may then continue progression along a pathway driven by more localized disturbances until the complex stage is reached, a catastrophic disturbance regenerates the stand, or development is altered by a subsequent intermediate-severity event.

We propose a revised conceptual model of oak stand development driven by canopy disturbance events (Figure 2). Our goal is to build on the concepts provided by prior authors using the Johnson et al. [4] framework as an archetype. Our revised model of oak stand development differs from the existing model in three fundamental ways. First, our proposed model acknowledges more than one mixed stage of development (i.e., a broad range of structural conditions) after an intermediate-severity disturbance based on the pre-disturbance condition (i.e., the stage of development) and disturbance agent. Second, we suggest that these discrete mixed stages may progress in their development along different pathways and may be structurally dissimilar when they reach the complex stage (i.e., they do not necessarily converge). Third, we contend that the complex stage of development is not usually achieved in the absence of the mixed stage. Below we provide our basis for these modifications and summarize our revised model of oak stand development. Based on the variability inherent in oak-dominated systems across the temperate zone, we present a conceptual framework rather than a mathematically derived classification scheme for understanding developmental pathways of oak stands. We note that our conceptual framework is appropriate for closed canopy oak stands (i.e., forests and woodlands) and may not be an appropriate framework for the development of oak stands with perpetual open canopies (i.e., oak savannas). 


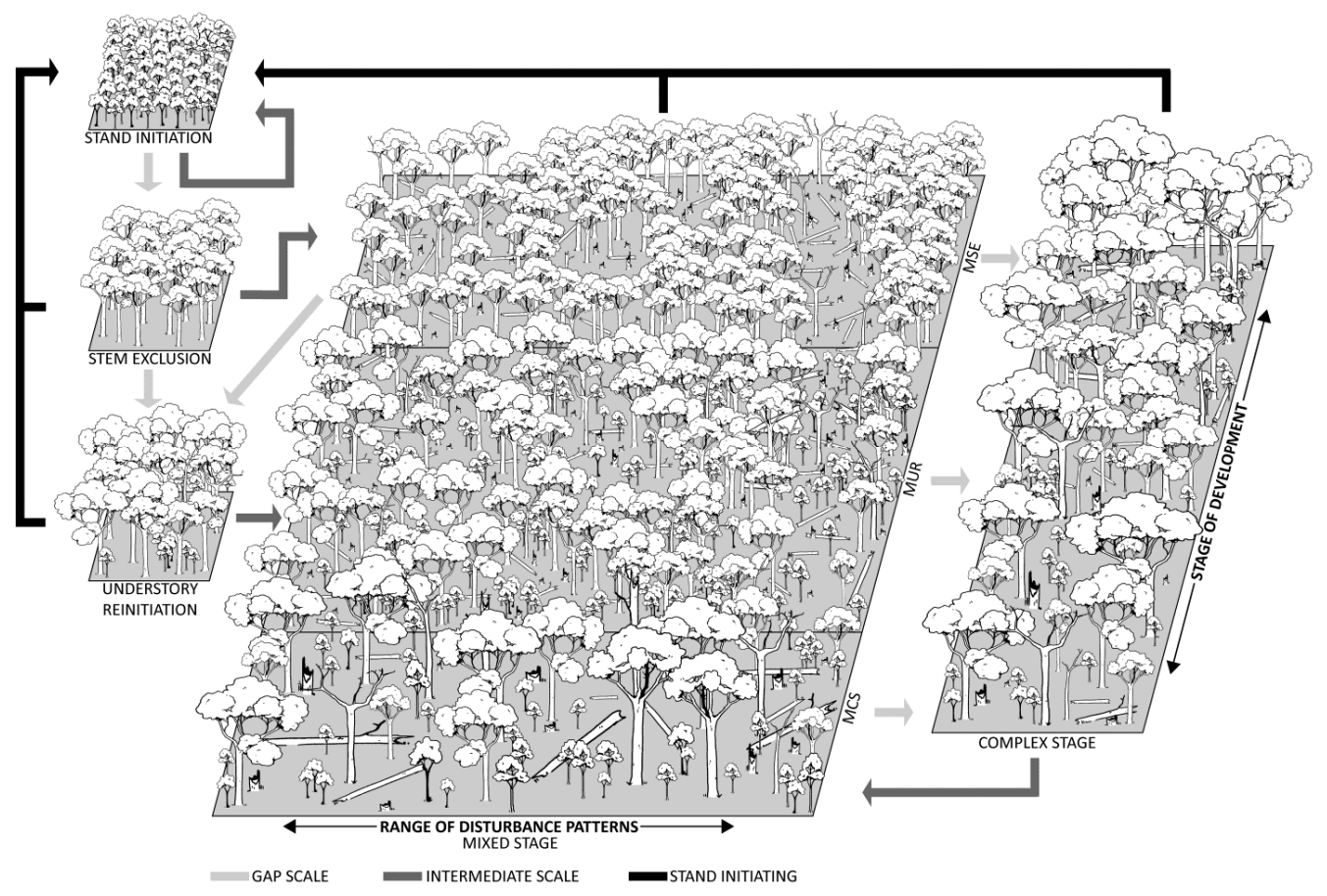

Figure 2. Conceptual model of oak stand development shaped by canopy disturbance events. Light gray lines indicate the developmental pathway driven by gap-scale disturbances, medium gray lines by intermediate-severity disturbances, and black lines by catastrophic disturbances. Note the variability of residual stand structures after intermediate-severity disturbance events is depicted to vary left to right from uniform to aggregated to linear patterns of tree mortality based on disturbance agent. The mixed stage is also depicted to vary top to bottom based on pre-disturbance condition (MSE: mixed stage from stem exclusion, MUR: mixed stage from understory reinitiation, and MCS: mixed stage from complex stage). Likewise, a wide range of structural conditions is depicted in the complex stage based on disturbance history.

\section{Conceptual Model of Oak Stand Development}

\subsection{Multiple Mixed Stages}

The current model of oak stand development only recognizes a single mixed stage following an intermediate-severity disturbance, regardless of the stage of development at the time of the event or disturbance agent. The response of a stand to a disturbance event is controlled in part by the pre-disturbance stand condition. Elements of stand structure, such as stem density, canopy tree height, quadratic mean diameter, crown volume, and the vertical distribution of foliage, differ between the stem exclusion and understory reinitiation stages of development. Therefore, it follows that the same intermediate-severity disturbance event would impact oak stands of these two stages of development differently (i.e., the same wind event would result in different structures based on the initial structural condition). For example, larger trees are more likely to be killed by strong wind events relative to smaller trees [19-23]. The mortality of these larger trees would result in larger canopy gaps and larger inputs of coarse woody debris. Characteristics of the disturbance may be driven by pre-disturbance structure. More work is needed to quantify the effects of intermediate-severity disturbances on oak stands at different stages of development, but it serves to reason that stands in the stem exclusion and understory reinitiation stages would not structurally resemble each other after an intermediate-severity disturbance event. We contend that intermediate-severity disturbances do not homogenize residual structures of stands that exhibit different pre-disturbance conditions. Therefore, our revised model of oak stand development recognizes a broad range of mixed stages based on the stage of development at the time of the disturbance event. 
Examples of natural intermediate-severity disturbance agents include low intensity tornadoes, ice storms, floods, mixed severity fires, insect outbreaks, and pathogens (Table 1). By definition, intermediate-scale disturbances are those greater in extent than gap-scale events, but not stand replacing. Thus, the range of disturbance events that may be classed as intermediate severity is considerably greater than the range of gap-scale and stand replacing events. This inherent variability in biological legacies, which represent the effects of prior disturbances [24,25], from intermediate-severity events makes forecasting the developmental pathway difficult and complicates model development. For example, two different intermediate-severity disturbance events may leave the same residual basal area in a stand, but the size, number, and spatial distribution of residual trees may be considerably different (note the range of mixed stage conditions depicted in Figure 2 with uniform, aggregated, and linear patterns of disturbance). A species-specific insect outbreak may remove trees singly or in small groups beyond the background mortality rate from throughout a stand (canopy gaps formed beyond the background rate would be an intermediate-severity event), whereas a low intensity tornado may remove most all trees in a linear swath, but leave the majority of the stand undisturbed $[23,26,27]$.

Table 1. Examples of studies that have examined intermediate-severity disturbances from a variety of disturbance agents in oak-dominated stands.

\begin{tabular}{|c|c|c|c|}
\hline Disturbance agent & Location & Dominant species & Citation \\
\hline Drought & North Carolina, USA & Mixed oak & [28] \\
\hline Flood & Illinois, USA & Mixed oak & [29] \\
\hline Flood & Tochigi Prefecture, Japan & Mongolian oak (Q. mongolica) & [30] \\
\hline Ice storm & Connecticut, USA & Northern red oak (Q. rubra) & {$[31]$} \\
\hline Ice storm & Missouri, USA & White oak (Q. alba), northern red oak & [32] \\
\hline Ice storm & Ohio, USA & Mixed oak, hickory (Carya spp.), tulip-poplar & [33] \\
\hline Ice storm & Virginia, USA & Chestnut oak (Q. prinus) & [34] \\
\hline Ice storm & Virginia, USA & Chestnut oak, white oak, scarlet oak (Q. coccinea) & [35] \\
\hline Ice storm & Virginia, USA & Mixed oak & [36] \\
\hline Insect outbreak & Pennsylvania, USA & Mixed oak & [37] \\
\hline Mixed severity fire & Algarve District, Portugal & Cork oak (Q. suber) & [38] \\
\hline Mixed severity fire & California, USA & California black oak (Q. kelloggii) & [39] \\
\hline Mixed severity fire & Indiana, USA & Black oak (Q. velutina) & [40] \\
\hline Pathogen & North Carolina, USA & Northern red oak & [41] \\
\hline Pathogen & North Carolina, USA & Mixed oak & [42] \\
\hline Pathogen & Tennessee, USA & White oak, tulip-poplar & [26] \\
\hline Pathogen & Virginia, USA & Chestnut oak, northern red oak, white oak & [43] \\
\hline Pathogen & Yamagata Prefecture, Japan & Mongolian oak & [44] \\
\hline Wind event & Alabama, USA & Mixed oak, hickory & [45] \\
\hline Wind event & Alabama, USA & White oak & [23] \\
\hline Wind event & Illinois, USA & Mixed oak & [46] \\
\hline Wind event & Jeju-do Province, South Korea & Mongolian oak & [47] \\
\hline Wind event & Missouri, USA & Mixed oak, overcup oak (Q. lyrata) & [20] \\
\hline Wind event & North Carolina, USA & Scarlet oak, chestnut oak, black oak & [48] \\
\hline Wind event & Oklahoma, USA & Blackjack oak (Q. marilandica), post oak (Q. stellata) & [49] \\
\hline
\end{tabular}

Based on pre-disturbance condition and disturbance agent, resultant structures from intermediate-severity disturbances may vary widely, not only horizontally, but also vertically. Impacts of an intermediate-severity disturbance in stem exclusion stage stands, with a single stratum, may substantially differ from the impacts of understory reinitiation or complex stage stands, which have two or more vertical strata. Tree crowns have not differentiated in stem exclusion stands and thus, these stands may not contain individuals that are more or less likely to be removed by intermediate-severity disturbances because of tree traits. However, in multi-strata stands larger trees in dominant positions may be more susceptible to windthrow or damage from glaze accumulation and small trees may be more susceptible to some fire events.

We emphasize that the mixed stage should not be confused with the complex stage of development. Mixed stage stands may contain a single age class of canopy trees and may not contain large trees at wide spacings that characterize older, complex stage stands. Although an intermediate-severity 
disturbance may enhance structural complexity, these events do not by themselves create the structures epitomized by stands in the complex stage. In this respect, our proposed model does not differ from Johnson et al. [4].

\subsection{Development of Mixed Stage Stands}

Based on the current model of oak development, in the absence of additional exogenous disturbance, stands in the mixed stage would transition to the complex stage via gap-scale processes. As the impacts of intermediate-severity disturbances would be different based on stage of development, so should the responses of the stands. The stem exclusion phase, for example, lacks advanced reproduction to take advantage of new growing space, the smaller and younger canopy trees during this phase may sprout more prolifically, and the residual canopy trees may respond more vigorously relative to later stages of development [50-53]. Additionally, if the intermediate-severity event resulted in uniform mortality (i.e., trees killed individually rather than in groups), the openings formed by the loss of canopy trees in the stem exclusion phase may be smaller and the vigorous perimeter trees may close the voids relatively quickly. Although these openings may provide a mechanism for seeds to germinate and perhaps for seedlings to establish, the probability of canopy accession by one of these new germinates would be relatively low. Depending on the severity of the intermediate-severity event, the developmental pathway of an impacted stem exclusion stage stand may result in a mixed stage stand that subsequently progresses to either the understory reinitiation stage or the complex stage of development. For example, if the intermediate-severity event consisted of gap-scale disturbances created beyond the background rate, the stands would enter the mixed stage. This phase may be short-lived however as the disturbance may provide for the establishment of advanced reproduction. As an understory layer develops and canopy openings close, the stand would shift to the understory reinitiation stage, but material and information legacies would remain in the system [24,25]. In this example, the duration of the mixed stage may be influenced by a variety of factors including the sprouting potential of killed trees, seed production of residual trees, and the suitability of the seedbed for germination and stem establishment. In contrast to the above scenario, canopy openings created by an intermediate-severity disturbance with a uniform mortality pattern during the understory reinitiation phase would be larger, as gap size is influenced by canopy tree size. Advanced reproduction would exist during the understory reinitiation stage of development and thus, the probability of gap capture by a sub-canopy tree would be much higher relative to the same event during the stem exclusion phase $[12,17]$. Understory reinitiation stage stands impacted by an intermediate-severity event would enter the mixed stage and in the absence of another incomplete stand-scale disturbance would progress to the complex stage. Thus, oak stand development may not be linear and deterministic. Multiple developmental pathways may exist, and these pathways may be more web-like than linear.

The spatial pattern of the intermediate-severity disturbance, resulting from different disturbance agents, may be a strong influence on subsequent development. Intermediate-severity events that remove trees uniformly throughout a stand cause a transition to the mixed stage, but this stage may be ephemeral. Such events may ultimately accelerate development to later stages. Intermediate-severity disturbances that result in clustered mortality patterns (patch or linear mortality) may allow for the establishment of a new age class. These openings would be larger and thus exist for longer periods, which increases the probability of canopy accession by new germinates or advanced regeneration. The spatial pattern of canopy disturbance may influence the scale of structural heterogeneity of the affected stand. A uniform disturbance may create fine-scale heterogeneity, whereas patch or linear mortality would exhibit structural complexity at a broader scale. The spatial configuration of dead canopy trees and the sizes of the canopy openings are strong influences on subsequent development.

The structural characteristics of stands in the complex stage may reflect their unique disturbance histories (i.e., ecological memory) and may be dissimilar to stands that were impacted by an intermediate-severity disturbance at another point during their development or a different intermediate-severity disturbance agent (note the range of complex stage conditions depicted in 
Figure 2). The different effects on stand structure and responses to an intermediate-severity disturbance based on pre-disturbance condition and disturbance agent, may in part explain why even simple structural measures, such as stem density, basal area, quadratic mean diameter, and q-factor, vary so widely even in stands with similar species composition and in the same biophysical region [54,55]. Additionally, complex stage stands may be impacted by intermediate-severity disturbance and enter the mixed stage of development. Intermediate-severity disturbances in complex stage stands would result in an increased land fraction in high light environments, and may result in a reduced number of large canopy trees that epitomize the complex phase as these individuals may be more susceptible to some exogenous canopy disturbance agents relative to smaller sized stems.

\subsection{Intermediate-Severity Disturbance Frequency}

We contend that the complex stage of development is not usually reached in the absence of the mixed stage. This hypothesis underscores why it is important to acknowledge that a range of mixed stages can occur based on pre-disturbance condition and disturbance agent, and that mixed stage stands may progress along different developmental pathways. We do not suggest that an intermediate-severity disturbance is essential to achieve a structurally complex oak stand or initiate some essential function, but rather the return interval of intermediate-severity disturbances in oak stands is shorter than the period required for stands to reach the complex developmental phase via gap-scale disturbance alone. Theoretically, an oak stand could reach the complex stage via gap-scale disturbances only but in reality, this does not often occur based on the return interval of intermediate-severity events. Disturbance history reconstructions using tree-ring records and forest inventory data have been conducted in some oak stands of the eastern USA. The studies have shown that the return interval of disturbance events that removed trees from at least $25 \%$ of the stand was typically $20-50$ years [6,26,56-61]. Disturbances of this spatial extent and severity would be classified as intermediate-scale events. Collectively, such disturbances are relatively common in the temperate zone. For example, over 1250 tornadoes occur in the USA annually [62] and over 13,500 instances of damaging winds (wind speeds $\geq 80 \mathrm{kph}$ ) were reported in the USA in 2016 alone [63]. For some oak-dominated sites the return interval of ice storms may be as short as 20 years [58,64]. Thus, we posit most all oak stands pass through the mixed stage of development at least once prior to reaching the complex stage.

\section{Implementation and Management Implications}

Quantitative stand structural measures for pre- and post-intermediate-severity disturbance are needed to test this conceptual model of development. Specifically, data for stand basal area, tree density, diameter structure, horizontal patterns of live and dead stems, vertical distribution of tree crowns, and canopy openness are required to test the efficacy of the proposed conceptual framework [15]. With additional quantitative data, it may be possible to subdivide the broad mixed stage we propose into discrete categories and to provide developmental pathways for each. Information on long-term disturbance history from retrospective studies or permanent monitoring plots is also needed to provide more information on the return interval of disturbances across different severities. Pre- and post-disturbance stand structural data and disturbance history reconstructions are available for some oak-dominated stands, but the sample size is insufficient because of the variability of stand conditions in oak-dominated systems of the temperate zone. Disturbance response in oak stands may differ depending on co-occurring taxa. For example, stands with abundant shade-tolerant species, such as red maple (Acer rubrum), may respond differently than those where shade-intolerant species, such as tulip-poplar (Liriodendron tulipifera) often colonize disturbed environments. With a larger dataset, it would be possible to develop a dichotomous key based on simple stand structural measures (e.g. basal area by tree size classes) to classify stands to the stage of development [15]. Such a model may have to be adjusted to accommodate oak stands on extremely high productivity and low productivity sites.

Our conceptual model highlights the wide range of potential stand structures that may occur naturally because of canopy disturbance in oak-dominated systems. These structures may be used to 
guide management targets and actions. It is also important for managers to understand how stands might respond to natural or anthropogenic intermediate-severity disturbances and how development might proceed following such events. Our conceptual framework provides managers with a more comprehensive understanding of stand developmental pathways and disturbance events, which should prove especially useful for those that wish to develop silvicutural systems based on natural disturbance processes and developmental patterns. Most oak stands in the eastern USA are managed in an even-aged system that treats entire stands uniformly. Managers that desire to follow a natural disturbance-based silviculture approach, in attempt to enhance native forest diversity, maintain ecosystem functions, and promote resiliency to future perturbations, might consider applying even-aged treatments in groups rather than evenly through a stand. The group opening sizes and shapes could be based upon those that result from natural intermediate-severity disturbance events. The return interval of stand entries may be based upon the return interval of natural intermediate-severity disturbances. Reserve trees in the group openings could be retained at variable densities. Such a system would promote intra-stand heterogeneity and result in two or more age classes at the stand-scale. An example would be a system that uses group shelterwoods with reserves with successive harvest entries timed at 20-50 year intervals. Such a system would entail relatively frequent entries, but would also allow for a wide range of potential stand structures to achieve a wide range of management objectives.

\section{Conclusions}

We hypothesize that oak stand development is not necessarily deterministic and linear, but may follow multiple pathways. Our conceptual framework of oak stand development incorporates the influence of intermediate-severity disturbance events, outlines the possibility of multiple pathways, and does not narrowly define an endpoint given the stochastic nature of natural disturbances. Our model differs from the current oak stand development model in three primary ways. First, our proposed model acknowledges more than one mixed stage of development after an intermediate-severity disturbance based on the pre-disturbance condition and disturbance agent. Second, we suggest that these discrete mixed stages may progress in their development along different pathways and may be structurally dissimilar when they reach the complex stage. Thus, the mixed and complex stages are relatively broad classes as they may represent a wide range of structural conditions. Third, we contend that the complex stage of development is not typically achieved in the absence of the mixed stage, not because intermediate-severity disturbances are essential, but rather because the return interval of such events is shorter than the period required for oak stands to reach the complex developmental phase via gap-scale disturbance alone. Our proposed model illustrates that oak stands progress from one stage to the next via gap-scale disturbance processes, but superimposed over this background disturbance regime are intermediate-severity disturbances that alter, temporarily or permanently, the developmental pathway. Catastrophic disturbances at any point during development reset the system to the stand initiation stage of development. Intermediate-severity disturbances play important roles in the development of temperate oak stands. These stochastic events make stand developmental pathways complex, and acknowledging that oak stand development may have a web-like nature with multiple pathways should improve our ability to manage the oak resource.

Conflicts of Interest: The authors declare no conflict of interest.

\section{References}

1. O'Hara, K.L. Multiaged Silviculture: Managing for Complex Forest Stand Structures; Oxford University Press: Oxford, UK, 2014.

2. Oliver, C.D.; Larson, B.C. Forest Stand Dynamics; Wiley: New York, NY, USA, 1996.

3. Johnson, P.S.; Schifley, S.R.; Rogers, R. The Ecology and Silviculture of Oaks, 1st ed.; CAB International: Cambridge, MS, USA, 2002. 
4. Johnson, P.S.; Schifley, S.R.; Rogers, R. The Ecology and Silviculture of Oaks, 2nd ed.; CAB International: Cambridge, MA, USA, 2009.

5. Zeide, B. How to measure stand density. Trees 2005, 19, 1-14. [CrossRef]

6. Hart, J.L.; Grissino-Mayer, H.D. Vegetation patterns and dendroecology of a mixed hardwood forest on the Cumberland Plateau: Implications for stand development. For. Ecol. Manag. 2008, 255, 1960-1975. [CrossRef]

7. Hart, J.L.; Bhuta, A.A.R.; Schneider, R.M. Canopy disturbance patterns in secondary hardwood stands on the Highland Rim of Alabama. Castanea 2011, 76, 55-63. [CrossRef]

8. Lorimer, C.G. Development of the red maple understory in northeastern oak forests. For. Sci. 1984, 30, 3-22.

9. Abrams, M.D. The red maple paradox. BioScience 1998, 48, 355-364. [CrossRef]

10. Nowacki, G.J.; Abrams, M.D. Demise of fire and mesophication of eastern U.S. forests. BioScience 2008, 58, 123-138. [CrossRef]

11. Hart, J.L.; Grissino-Mayer, H.D. Gap-scale disturbance processes in secondary hardwood stands on the Cumberland Plateau, Tennessee, USA. Plant Ecol. 2009, 201, 131-146. [CrossRef]

12. Richards, J.D.; Hart, J.L. Canopy gap dynamics and development patterns in secondary Quercus stands on the Cumberland Plateau, Alabama, USA. For. Ecol. Manag. 2011, 262, 2229-2239. [CrossRef]

13. Himes, J.M.; Rentch, J.S. Canopy gap dynamics in a second-growth Appalachian hardwood forest in West Virginia. Castanea 2013, 78, 171-184. [CrossRef]

14. Weber, T.A.; Hart, J.L.; Schweitzer, C.J.; Dey, D.C. Influence of gap-scale disturbance on developmental and successional pathways in Quercus-Pinus stands. For. Ecol. Manag. 2014, 331, 60-70. [CrossRef]

15. Lorimer, C.G.; Halpin, C.R. Classification and dynamics of developmental stages in late-successional temperate forests. For. Ecol. Manag. 2014, 334, 344-357. [CrossRef]

16. Rentch, J.S.; Fajvan, M.A.; Hicks, R.R., Jr. Oak establishment and canopy accession strategies in five old-growth stands in the Central Hardwood forest region. For. Ecol. Manag. 2003, 184, 285-297. [CrossRef]

17. Webster, C.R.; Lorimer, C.G. Minimum opening sizes for canopy recruitment of midtolerant tree species: A retrospective approach. Ecol. Appl. 2005, 15, 1245-1262. [CrossRef]

18. Zeide, B. Comparison of self-thinning models: An exercise in reasoning. Trees 2010, 24, 1117-1126. [CrossRef]

19. Foster, D.R.; Boose, E.R. Patterns of forest damage resulting from catastrophic wind in central New England, USA. J. Ecol. 1992, 80, 79-98. [CrossRef]

20. Peterson, C.J.; Rebertus, A.J. Tornado damage and initial recovery in three adjacent, lowland temperate forests in Missouri. J. Veg. Sci. 1997, 8, 559-564. [CrossRef]

21. Peterson, C.J. Consistent influence of tree diameter and species on damage in nine eastern North America tornado blowdowns. For. Ecol. Manag. 2007, 250, 96-108. [CrossRef]

22. White, S.D.; Hart, J.L.; Schweitzer, C.J.; Dey, D.C. Altered structural development and accelerated succession from intermediate-scale wind disturbance in Quercus stands on the Cumberland Plateau, USA. For. Ecol. Manag. 2015, 336, 52-64. [CrossRef]

23. Cox, L.E.; Hart, J.L.; Dey, D.C.; Schweitzer, C.J. Composition, structure, and intra-stand spatial patterns along a disturbance severity gradient in a Quercus stand. For. Ecol. Manag. 2016, 381, 305-317. [CrossRef]

24. Johnstone, J.F.; Allen, C.D.; Franklin, J.F.; Frelich, L.E.; Harvey, B.J.; Higuera, P.E.; Mack, M.C.; Meentemeyer, R.K.; Metz, M.R.; Perry, G.L.W.; et al. Changing disturbance regimes, ecological memory, and forest resilience. Front. Ecol. Environ. 2016, 14, 369-378. [CrossRef]

25. Jogiste, K.; Korjus, H.; Stanturf, J.A.; Frelich, L.E.; Baders, E.; Donis, J.; Jansons, A.; Kangur, A.; Koster, K.; Laarmann, D.; et al. Hemiboreal forest: Natural disturbances and the importance of ecosystem legacies to management. Ecosphere 2017, 8, e01706. [CrossRef]

26. Hart, J.L.; van de Gevel, S.L.; Grissino-Mayer, H.D. Forest dynamics in a natural area of the southern Ridge and Valley, Tennessee. Nat. Areas J. 2008, 28, 275-289. [CrossRef]

27. Keasberry, A.M.; Hart, J.L.; Dey, D.C.; Schweitzer, C.J. Spatial patterns of irradiance and advanced reproduction along a canopy disturbance severity gradient in an upland hardwood stand. Forests 2016, 7, 73. [CrossRef]

28. Elliot, K.J.; Swank, W.T. Impacts of drought on tree mortality and growth in a mixed hardwood forest. J. Veg. Sci. 1994, 5, 229-236. [CrossRef]

29. Cosgriff, R.J.; Nelson, J.C.; Yin, Y. Floodplain forest response to large-scale flood disturbance. Trans Ill. State Acad. Sci. 2007, 100, 47-70. 
30. Sakai, T.; Tanaka, H.; Shibata, M.; Suzuki, W.; Nomiya, H.; Kanazashi, T.; Iida, S.; Nakashizuka, T. Riparian disturbance and community structure of a Quercus-Ulmus forest in central Japan. Plant Ecol. 1999, 140, 99-109. [CrossRef]

31. Covey, K.R.; Barrett, A.L.; Ashton, M.S. Ice storms as a successional pathway for Fagus grandifolia advancement in Quercus rubra dominated forests of southern New England. Can. J. For. Res. 2015, 45, 1628-1635. [CrossRef]

32. Rebertus, A.J.; Shifley, S.R.; Richards, R.H.; Roovers, L.M. Ice storm damage to an old-growth oak-hickory forest in Missouri. Am. Midl. Nat. 1997, 137, 48-61. [CrossRef]

33. Turcotte, R.M.; Elliott, T.R.; Fajvan, M.A.; Park, Y.L.; Snider, D.A.; Tobin, P.C. Effects of ice storm damage on hardwood survival and growth in Ohio. North. J. Appl. For. 2012, 29, 53-59. [CrossRef]

34. Lafon, C.W. Forest disturbance by ice storms in Quercus forests of the southern Appalachian Mountains. Ecoscience 2006, 13, 30-43. [CrossRef]

35. Warrillow, M.; Mou, P. Ice Storm damage to forest tree species in the Ridge and Valley region of southwestern Virginia. J. Torrey Bot. Soc. 1999, 126, 147-158. [CrossRef]

36. Whitney, H.E.; Johnson, W.C. Ice storms and forest succession in southwestern Virginia. Bull. Torrey Bot. Club 1984, 111, 429-437. [CrossRef]

37. Fajvan, M.A.; Wood, J.M. Stand structure and development after gypsy moth defoliation in the Appalachian Plateau. For. Ecol. Manag. 1996, 89, 79-88. [CrossRef]

38. Catry, F.X.; Moreira, F.; Duarte, I.; Acacio, V. Factors affecting post-fire crown regeneration in cork oak (Quercus suber L.) trees. Eur. J. For. Res. 2009, 128, 231-240. [CrossRef]

39. Cocking, M.I.; Varner, J.M.; Knapp, E.E. Long-term effects of fire severity on oak-conifer dynamics in the southern Cascades. Ecol. Appl. 2014, 24, 94-107. [CrossRef] [PubMed]

40. Henderson, N.R.; Long, J.N. A comparison of stand structure and fire history in two black oak woodlands in northwestern Indiana. Bot. Gaz. 1984, 145, 222-228. [CrossRef]

41. van de Gevel, S.L.; Hart, J.L.; Spond, M.D.; White, P.B.; Sutton, M.N.; Grissino-Mayer, H.D. American chestnut to northern red oak: Forest dynamics in an old-growth forest in the Blue Ridge Mountains, USA. Botany 2012, 90, 126-1276. [CrossRef]

42. Keever, C. Present composition of some stands of the former oak-chestnut forest in the southern Blue Ridge Mountains. Ecology 1953, 34, 44-54. [CrossRef]

43. McCormick, J.F.; Platt, R.B. Recovery of an Appalachian forest following the chestnut blight or Catherine Keever-you were right! Am. Midl. Nat. 1980, 104, 264-273. [CrossRef]

44. Oguroa, M.; Imahiroa, S.; Saitob, S.; Nakashizukaa, T. Relative importance of multiple scale factors to oak tree mortality due to Japanese oak wilt disease. For. Ecol. Manag. 2015, 356, 173-183. [CrossRef]

45. Cowden, M.M.; Hart, J.L.; Schweitzer, C.J.; Dey, D.C. Effects of intermediate-scale wind disturbance on composition, structure, and succession in Quercus stands: Implications for natural disturbance-based silviculture. For. Ecol. Manag. 2014, 330, 240-251. [CrossRef]

46. Holzmueller, E.J.; Gibons, D.J.; Suchecki, P.F. Accelerated succession following an intense wind storm in an oak-dominated forest. For. Ecol. Manag. 2012, 279, 141-146. [CrossRef]

47. Altman, J.; Dolezal, J.; Cerny, T.; Song, J.S. Forest response to increasing typhoon activity on the Korean peninsula: Evidence from oak tree-rings. Glob. Chang. Biol. 2013, 19, 498-504. [CrossRef] [PubMed]

48. Greenberg, C.H.; McNab, W.H. Forest disturbance in hurricane-related downbursts in the Appalachian mountains of North Carolina. For. Ecol. Manag. 1998, 104, 179-191. [CrossRef]

49. Myster, R.W.; Malahy, M.P. Tornado effects on damage, resprouting and spatial heterogeneity in the Cross Timbers ecotone of Oklahoma, USA. J. Plant Ecol. 2010, 3, 157-163. [CrossRef]

50. Johnson, P.S. Predicting Oak Stump Sprouting and Sprout Development in the Missouri Ozarks; Research Paper NC-149; USDA Forest Service, North Central Forest Experiment Station: St. Paul, MN, USA, 1977.

51. McGee, C.E. Size and Age of Tree Affect White Oak Stump Sprouting; Reserch Note SO-239; USDA Forest Service, Southern Forest Experiment Station: New Orelans, LA, USA, 1978.

52. Dey, D.C.; Jensen, R.G. Stump sprouting potential for oaks in Missouri Ozark forests managed by evenand uneven-aged silviculture. In Proceedings of the Second Missouri Ozark Forest Ecosystem Project Symposium: Post-treatment Results of the Landscape Experiment, St. Louis, MO, USA, 17-18 October 2000; Shifley, S.R., Kabrick, J.M., Eds.; General Technical Report NC-227. USDA Forest Service, North Central Forest Experiment Station: St. Paul, MN, USA, 2002. 
53. Sands, B.; Abrams, M.D. The effects of stump diameter on sprout number and size for three oak species in a Pennsylvania clearcut. North. J. Appl. For. 2009, 26, 122-125.

54. Tyrrell, L.E.; Nowacki, G.J.; Crow, T.R.; Buckley, D.S.; Nauertz, E.A.; Niese, J.N.; Rollinger, J.L.; Zasada, J.C. Information About Old-Growth for Selected Forest Type Groups in the Eastern United States; GTR-NC-197; USDA Forest Service, North Central Forest Experiment Station: St. Paul, MN, USA, 1998.

55. Burrascano, S.; Keeton, W.S.; Sabatini, F.M.; Blasi, C. Commonality and variability in the structural attributes of moist temperate old-growth forests: A global review. For. Ecol. Manag. 2013, 291, 458-479. [CrossRef]

56. Nowacki, G.J.; Abrams, M.D. Radial-growth averaging criteria for reconstructing disturbance histories from presettlement-origin oaks. Ecol. Monogr. 1997, 67, 225-249. [CrossRef]

57. Ruffner, C.M.; Abrams, M.D. Relating land-use history and climate to the dendroecology of a 326-year old Quercus prinus talus slope forest. Can. J. For. Res. 1998, 28, 347-358. [CrossRef]

58. Lafon, C.W.; Speer, J.H. Using dendrochronology to identify major ice storm events in oak forests of southwestern Virginia. Clim. Res. 2002, 20, 41-54. [CrossRef]

59. Hart, J.L.; Clark, S.L.; Torreano, S.J.; Buchanan, M.L. Composition, structure, and dendroecology of an old-growth Quercus forest on the tablelands of the Cumberland Plateau, USA. For. Ecol. Manag. 2012, 266, 11-24. [CrossRef]

60. Hart, J.L.; Cowden, M.M.; Torreano, S.J.; Vestal, P.R. Disturbance, succession, and structural development of an upland hardwood forest on the Interior Low Plateau, Tennessee. Nat. Areas J. 2015, 35, 557-573. [CrossRef]

61. Ford, S.A.; Kleinman, J.S.; Hart, J.L. Spatial patterns of canopy disturbance, structure, and species composition in a multi-cohort hardwood stand. Forests 2017, 8, 93. [CrossRef]

62. National Climate Data Center. Tornado Climatology, US National Oceanic and Atmospheric Administration. Available online: http:/ / www.ncdc.noaa.gov/climate-information/extreme-events/ustornado-climatology (accessed on 15 July 2016).

63. Storm Prediction Center. US National Oceanic and Atmospheric Administration, National Weather Service. Available online: http://www.spc.noaa.gov/climo/online/monthly/2015_annual_summary.html (accessed on 1 April 2017).

64. Abell, C.A. Glaze storms in hardwood forests. J. For. 1934, 32, 35-37. 